\title{
ISOLAMENTO E CULTIVO DE PROTOPLASTOS DE PORTA-ENXERTOS DE CITROS
}

\author{
R.P. DE OLIVEIRA; B.M.J. MENDES, F.B. d' UTRA VAZ; A.TULMANN NETO \\ Centro de Energia Nuclear na Agricultura-CENA/USP, C.P. 96 - CEP: 13400-970 - Piracicaba,SP.
}

\begin{abstract}
RESUMO - Realizou-se o lsolamento e cultivo de protoplastos de porta-enxertos de citros das variedades limoeiro Cravo e tangerina Cleópatra. Utilizou-se solução enzimática para a digeståo da parede celular de células em suspensāo (7 a 10 subcultivos em melo de cultura MT) e procedeu-se a purificaçăo criteriosa. $O$ plaqueamento dos protoplastos foi realizado em meio de cultivo KM8p e na molaridade de $0.6 \mathrm{M}$, sob condlfóes de escuro a $28 \pm 1^{\circ} \mathrm{C}$, após ajuste para a densidade de 2 × $10^{5} \mathrm{ppts} / \mathrm{ml}$. A reduçăo da pressăo osmótica do meio de cultivo foi realizada a cada 10 dias na seguinte proporção de meio de cultura KM8p 0.6 M e KM8 (2:1, 1:1, 1:2, 0:3). Com relaçåo aos resultados, obteve-se em média o isolamento de $0.7 \times 10^{6} \mathrm{ppts} / \mathrm{ml}$ de suspensōes celulares de tangerina Cleópatra e $0.5 \times 10^{6} \mathrm{ppts} / \mathrm{ml}$ de suspensões de limoeiro Cravo, com uma porcentagem de viabilidade de 86 a $92 \%$ para a variedade Cleópatra e de 73 a $80 \%$ para o limoeiro Cravo. As divisōes celulares começaram a ocorrer por volta do $8^{\circ}$ dia após o plaqueamento, sendo obtida uma eficiêncla inicial de plaqueamento de $9 \%$ para a variedade Cleópatra e de $5 \%$ para o limoeiro Cravo. Aos 50 dias de cultivo, as colônias foram transferidas para melo semi-sólido MT, onde apresentaram ritmo acelerado de crescimento formando calos.
\end{abstract}

Descritores: porta-enxerto, citros, protoplastos

\section{ISOLATION AND GROWTH OF CITRUS ROOTSTOCK PROTOPLASTS}

SUMMARY - Protoplast isolation and growth of Citrus rootstock v. Cravo lime and Cleópatra mandarin were carried out. Enzyme mixture was used to digest cell suspensions 7-10 times, following criterious purification. Protoplast culture was carried out in doplets of semi-solid (agarose $0.6 \% \mathrm{p} / \mathrm{v}$ ) $\mathrm{KM8p}$ medium, in the dark, at $28 \pm 1^{\circ} \mathrm{C}$ following density adjustment to $2 \times 10^{5} \mathrm{ppts} / \mathrm{ml}$. Osmotic pressure reduction was acomplished for each growth every 10 days with a mixture in equal volumes of KM8p and KM8 medium in ratios of $2: 1 ; 1: 1 ; 1: 2$ e:3. Isolation produced $0.7 \times 10^{6} \mathrm{ppts} / \mathrm{ml}$ for Cleópatra mandarin and $0.5 \times 10^{6} \mathrm{ppts} / \mathrm{ml}$ for Cravo lime, with a viabllity between 86 to $92 \%$ and 73 to $80 \%$, respectively. First cell divisions were recorded at the 8 h. day of growth, with an inicial platting efficiency of $9 \%$ for Cleópatra mandarin and $\mathbf{5 \%}$ for Cravo lime. Callus development was achived in $\mathbf{5 0}$ days upon transfer of microcallus to semi-solid MT medium.

Key Words: rootstock, citrus, protoplasts

\section{INTRODUÇÃO}

O Brasil é o maior produtor e exportador mundial de suco cítrico concentrado (FAO, 1992). A área produtiva se localiza principalmente no estado de São Paulo, onde se utiliza de forma predominante o limoeiro Cravo como porta-enxerto (AMARO et al., 1991)

A hibridação somática através da fusão de protoplastos é um dos novos métodos que vem sendo utilizado no melhoramento de citros (GROSSER \& GMITTER Jr., 1990b). Os híbridos somáticos apresentam a grande vantagem de serem alotetraplóides, mantendo os genes dos pais por não haver segregação meiótica. Assim, os genes deletérios recessivos existentes nos pais não se expressam e as características controladas por genes dominan- tes ou codominantes presentes em um dos parentais podem se expressar nos hibridos (GROSSER \& GMTTTER, 1990a).

Os protoplastos de citros podem ser isolados a partir de folhas, flores, calos embriogênicos ou não e de células em suspensão (GROSSER \& GMITTER Jr., 1990a). Os principais fatores determinantes da eficiência no isolamento e cultivo de protoplastos estão relacionados ao genótipo, estado fisiológico das células, tipo e concentração de enzimas, tempo de incubação na solução enzimática, agitação, concentração e tipo de estabilizadores osmóticos, luminosidade e temperatura (GLEDDIE et al., 1985).

O presente trabalho teve por objetivo estabelecer metodologia para o isolamento e cultivo de protoplastos das variedades limoeiro Cravo e tangerina Cleópatra. 


\section{MATERIAL E METODOS}

Os experimentos foram realizados na Seção de Radiogenética do Centro de Energia Nuclear na Agricultura (CENA/USP), em Piracicaba-SP, utilizando as espécies Citrus reshni Hort. (tangerina Cleópatra) e Citrus limonia Osbeck (limoeiro Cravo), que correspondem aos principais porta-enxertos utilizados no Brasil.

$O$ isolamento dos protoplastos foi realizado utilizando-se o protocolo descrito por D'UTRA VAZ et al. (1993). Utilizou-se a solução enzimática descrita por OCHATT et al. (1987), composta por $0.2 \%$ $\mathrm{p} / \mathrm{v}$ de macerozyme R-10 (Yakult Honsha Co. Ltd., Tokyo, Japan), $1.0 \% \mathrm{p} / \mathrm{v}$ de cellulase "Onozuka" R10 (Yakult Honsha Co. Ltd., Tokyo, Japan), 0.1\% p/ $v$ de driselase (Kyowa Hakko Kogyo Co. Ltd., Tokyo, Japan), 5.0 mM de MES e $0.7 \mathrm{M}$ de manitol. Estes componentes foram dissolvidos em solução de nutrientes CPW descrita por POWER et al. (1989). O $\mathrm{pH}$ da solução enzimática foi ajustado para 5.6 e a solução filtrada em membrana de nitrocelulase de $0.2 \mu \mathrm{m}$.

Antes da digestão da parede celular, as células em suspensão ( 7 a 10 subcultivos em meio MT) foram plasmolizadas em $12 \mathrm{ml}$ de solução CPW 13\% p/v de manitol, por 1 hora (OCHATT et al., 1987). Em seguida, removeu-se a solução de plasmólise e adicionou-se $12 \mathrm{ml}$ de solução de enzima em $3 \mathrm{~cm}^{3}$ de células em suspensão, procedendo-se a incubação por 16 horas a $40 \mathrm{rpm}, 25 \pm 2^{\circ} \mathrm{C}$, sob condições de escuro (D'UTRA VAZ et al., 1993).

A purificação dos protoplastos isolados foi feita através de uma filtração, em peneira de nylon de $45 \mu \mathrm{m}$, e por uma sequência de centrifugaçóes (GROSSER \& GMITTER Jr., 1990a). A primeira e a segunda centrifugaçóes foram realizadas a $90 \times \mathrm{g}$ por 4 minutos, lavando-se os protoplastos com solução CPW, suplementada com $13 \% \mathrm{p} / \mathrm{v}$ de manitol. $\mathrm{Na}$ terceira centrifugação foi utilizado um gradiente de densidade composto por soluçбes CPW $21 \% \mathrm{p} / \mathrm{v}$ de sacarose e CPW 13\% p/v de manitol. O gradiente sacarose/manitol foi construído suspendendo o "pellets" obtido na centrifugação anterior em $2 \mathrm{ml}$ da solução CPW manitol. Posteriormente, esta solução foi adicionada, cuidadosamente, sobre $5 \mathrm{ml} \mathrm{da}$ solução CPW sacarose, em tubo de centrífuga de 10 $\mathrm{ml}$. A centrifugaçăo foi feita a $90 \times \mathrm{g}$ por $10 \mathrm{minu-}$ tos. Em seguida, com o auxilio de pipeta de Pasteur, os protoplastos, da banda que se formou entre as duas soluçóes, foram removidos e suspendidos em solução CPW manitol para nova lavagem. Durante esta etapa, foram realizadas contagens em câmara de Newbauer do número de protoplastos isolados.

A viabilidade dos protoplastos purificados foi estudada utilizando o corante azul de metileno na concentração final de $0.01 \% \mathrm{p} / \mathrm{v}$ (HOOLEY \& McCARTHY, 1980). Foram analisadas a viabilidade de 200 protoplastos após cada isolamento, sendo feitas contagens do número de protoplastos viáveis e mortos em microscópio invertido. Nesta fase também foi analisado o diâmetro dos protoplastos, sendo também utilizadas 200 repetições. Esta avaliação foi realizada em microscópio invertido utilizando uma lente graduada que foi calibrada com uma lâmina de graduação.

O plaqueamento de protoplastos de tangerina Cleópatra e limoeiro Cravo foi feito no meio de cultivo KM8p (GILMOUR et al,, 1989), na molaridade de $0.6 \mathrm{M}$, sob condições de escuro a 28 $\pm 1^{\circ} \mathrm{C}$, após ajuste para a densidade de $2 \mathrm{x}$ $10^{5}$ prot./ml (GROSSER \& GMITTER Jr., 1990a).

$\mathrm{O}$ método de plaqueamento utilizado foi $\mathrm{em}$ gotas de KM8p, solidificadas com $0.6 \% \mathrm{p} / \mathrm{v}$ de agarose (SHILLITO et al., 1983). Aproximadamente 25 gotas de $40 \mu 1$ foram colocadas por placa de Petri de $5 \mathrm{~cm}$ de diâmetro, adicionando, em seguida, $2 \mathrm{ml}$ de meio de cultura KM8p na forma líquida (D'UTRA VAZ et al., 1993).

A redução da pressão osmótica do meio de cultivo foi realizada a cada 10 dias na seguinte proporção de meio de cultura KM8p 0.6 M e KM8 (2:1, 1:1, 1:2,0:3). As divisð̃es celulares e formaça de colônias foram acompanhadas através de microscópio invertido.

Quatorze dias após o início do cultivo foi avaliada a eficiência de plaqueamento inicial dos protoplastos das variedades estudadas (número de células em divisão / número total de células). Em cada isolamento foram realizadas 75 contagens ( 3 placas de Petri $\times 5$ gotas plaqueadas $x 5$ campos do microscópio invertido).

\section{RESUltados E DISCUSSÃo}

A utilização da solução enzimática de OCHATT et al. (1987), recomendada por D'UTRA VAZ et al. (1993), possibilitou, em média, o isolamento de $0.7 \times 10^{6}$ protoplastos $/ \mathrm{ml}$ de suspens $\widetilde{e}$ es celulares de tangerina Cleópatra e $0.5 \times 10^{6}$ protoplastos / $\mathrm{ml}$ de suspensőes de limoeiro Cravo, utilizando-se células na fase de crescimento logaritmico (Figura 1a). 


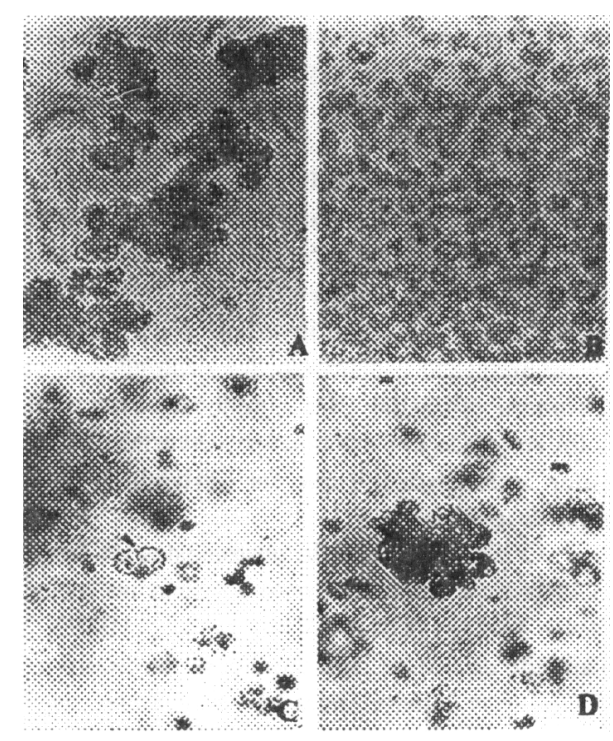

Figura 1. a) Células em suspensão de tangerina Cleópatra em meio de cultura EME; b) Protoplastos de tangerina Cleópatra após a purificação; c) Primeiras divisóes celulares 8 dias após o plaqueamento dos protoplastos; d) Colônias de células de tangerina Cleópatra 30 dias após o plaqueamento (x 200).

$\mathrm{Na}$ literatura não foram encontrados dados sobre a eficiência de isolamento de protoplastos a partir de suspensões celulares de citros. No entanto, em outras espécies lenhosas, como a cerejeira (Prunus avium $\times$ Pseudocerasus), foi obtida uma eficiência de $0.6 \times 10^{7}$ a $1.5 \times 10^{8}$ protoplastos $/ g$ de peso fresco (OCHATT et al., 1987), ao utilizar-se a mesma solução enzimática empregada no presente trabalho.

A purificação dos protoplastos de tangerina Cleópatra e limoeiro Cravo foi realizada seguindo a metodologia descrita por GROSSER \& GMTTTER Jr. (1990a). No entanto, somente foram obtidos resultados adequados quando foi introduzida a seguinte modificação: no momento de construir o gradiente sacarose/manitol, suspendeu-se os protoplastos isolados em solução de manitol ao invés de na solução de sacarose. Esta alteração foi realizada pelo fato de na solução manitol a $13 \% \mathrm{p} / \mathrm{v}$ os protoplastos possuirem maior mobilidade do que na solução de sacarose $21 \% \mathrm{p} / \mathrm{v}$. Isto ocorre devido à menor densidade da solução que contém manitol. Dessa maneira, os protoplastos intactos se deslocam até a posi- ção da interface entre as duas soluçðes, ao passo que os estourados, pedaços de células e demais debris deslocam-se para o fundo dos tubos da centrifuga. Por outro lado, ao executar-se o procedimento descrito por GROSSER \& GMITTER Jr. (1990a), verificou-se que tanto os protoplastos intactos como os outros componentes se depositavam no fundo dos tubos, após a centrifugação.

$\mathrm{Na}$ Figura $1 \mathrm{~b}$ podem ser analisados protoplastos isolados de suspensốes celulares de tangerina Cleópatra após a purificação. Nesta Figura também se verifica a presença, em pequena porcentagem, de protoplastos maiores decorrentes de fusőes espontâneas. Resultados semelhantes foram obtidos por GOLDMAN (1988), que obteve 3\% de protoplastos binucleados em laranja 'Pêra', avaliados através do método de coloração de núcleos com fucsina carbólica, descrito por KAO (1982). A ocorrência de baixa frequência de fusōes espontâneas nos experimentos realizados indica boa adequação da soluçåo enzimática ao material vegetal utilizado para 0 isolamento de protoplastos.

Os protoplastos isolados caracterizaram-se por apresentarem diâmetro variando de 4.8 a 16.8 $\mu \mathrm{m}$ em tangerina Cleópatra e de 4.8 a $14.4 \mu \mathrm{m}$ em limoeiro Cravo. Segundo ZIMMERMANN \& SCHEVRICH (1981), o conhecimento do diâmetro dos protoplastos é importante em trabalhos de fusåo usando o método de eletrofusão, pois existe uma relaçẫo inversa entre o diâmetro e a voltagem necessária para a fusão dos protoplastos.

Nos experimentos realizados, a viabilidade dos protoplastos isolados a partir de suspensóes celulares variou de 86 a $92 \%$ para a variedade Cleópatra e de 73 a $80 \%$ para o limoeiro Cravo. Esses resultados foram obtidos utilizando-se 0 corante azul de metileno na concentraç̃̃o final de $0.01 \% \mathrm{p} /$ v, e aproximam-se daqueles obtidos por GOLDMAN (1988), de 79.47 a $89.50 \%$ ao utilizar o mesmo metodo de avaliação e por CRISTOFANI (1991), de 80.68 a $84.03 \%$ ao utilizar o método com diacetato de fluoresceina. Ambos os autores trabalharam com protoplastos obtidos a partir de calos de laranja 'Pêra'. E interessante destacar, também, que os protoplastos obtidos a partir de suspensôes celulares de limoeiro Cravo apresentam menor viabilidade, o que parece estar relacionado, principalmente, ao tipo de suspensão celular utilizada. É provável, que a realização de modificaçóes no meio de cultivo das células de limoeiro Cravo melhore o estado das suspensões celulares, resultando em maior viabilidade dos protoplastos. 
$O$ cultivo foi realizado plaqueando-se os protoplastos em gotas solidificadas com agarose, e adicionando-se uma camada de meio líquido sobre as gotas (SHIILLITO et al., 1983). Esse método foi bastante eficiente permitindo adequada formação de colônias de células. Em ensaios preliminares, trabalhou-se com o método de plaqueamento em gotas não solidificadas, descrito por KAO et al. (1970). Obteve-se divisðes iniciais que não progrediram, havendo morte dos protoplastos por plasmólise, devido a evaporacáa de água.

A habilidade dos protoplastos em se dividirem e formarem colônias é altamente dependente da densidade celular e da composição do meio de cultura (CARNEIRO \& CONROI, 1990). Neste estudo, utilizou-se o meio de cultivo KM8p e a densidade de plaqueamento de $2 \times 10^{5}$ protoplastos $/ \mathrm{ml}$.

No cultivo de protoplastos, a maioria das espécies vegetais requerem a presença de auxinas ou de citocininas para regenerarem a parede celular e se dividirem (GLEDDIE et al., 1985). O meio de cultura KM8p contém $0.2 \mathrm{mg} /$ de 2,4-D, $1.0 \mathrm{mg} / \mathrm{l}$ de NAA e $0.5 \mathrm{mg} / \mathrm{de}$ zeatina, que é recomendado para espécies lenhosas (OCHATT et al, 1987). Esse meio de cultura apresentou resultados adequados, não sendo observado rompimento dos protoplastos pelo aumento do volume de seus vacúolos ou pela formação de novos vacúolos, efeitos esses normalmente causados pelo uso de auxinas e de outros reguladores no meio de cultivo de protoplastos (VASIL \& VASIL, 1980).

Segundo SPIEGEL-ROY \& VARDI (1984), as espécies de citros, são capazes de regenerar a parede celular em meio de cultura sem reguladores de crescimento, devido a síntese endógena de hormônios. GROSSER \& GMITTER Jr. (1990a) utilizam os meios $\mathrm{BH}_{3}$ e EME para o cultivo de protoplastos de várias espécies de citros. $\mathrm{O}$ meio $\mathrm{BH}_{3}$ é semelhante ao meio KM8p, diferindo apenas por não possuir reguladores de crescimento. $O$ meio de cultura EME foi utilizado neste estudo para o cultivo de células em suspensão, não possuindo também reguladores de crescimento. Embora, nos experimentos realizados, tenham sido obtidos resultados satisfatórios com o meio de cultivo KM8p, recomenda-se que, em ensaios posteriores, sejam testados os meios $\mathrm{BH}_{3}$ e o EME.

Com relação à densidade de plaqueamento, GROSSER \& GMITTER Jr. (1990a) e VARDI et al. (1975) recomendam o valor de $1.0 \times 10^{5}$ protoplastos/ $\mathrm{ml}$ de meio de cultivo. No presente trabalho foi utilizado $2 \times 10^{5}$ protoplastos $/ \mathrm{ml}$ das gotas plaqueadas, pois foi adicionado $2 \mathrm{ml}$ de meio de cultura líquido em cada placa. Nas variedades estudadas, sempre se obteve elevada eficiência de isolamento de protoplastos, permitindo o plaqueamento nas densidades recomendadas.

Nos experimentos realizados, as divisర̃es celulares começaram a ocorrer por volta do $8^{\circ}$ dia após o plaqueamento (Figura 1c). Esses resultados se aproximam daqueles obtidos por GROSSER \& GMITTER Jr. (1990a) e por VARDI \& GALUN (1988), que obtiveram as primeiras divisões celulares após um período de 10 a 14 dias nos meios de cultivo $\mathrm{BH}_{3}$ e EME, repectivamente. É provável que, neste estudo, as divisôes tenham ocorrido precocemente devido a presença de reguladores de crescimento no meio de cultivo. $\mathrm{Na}$ fase inicial de divisão celular foi obtida uma eficiência de plaqueamento de $9 \%$ para a variedade Cleópatra e de $5 \%$ para o limoeiro Cravo. Esses resultados assemelham-se aos encontrados por VARDI et al. (1975), que trabalhando com outras espécies de citros obtiveram uma eficiência de plaqueamento inicial de 3.6 a $9.0 \%$.

Trinta dias após o plaqueamento foi observada a existência de diversas colônias de células de tangerina Cleópatra e limoeiro Cravo no meio de cultivo (Figura 1c). Aos 50 dias de cultivo, quando se completou a redução da pressão osmótica do meio, as colônias de células estavam visiveis a olho nu. Por essa razão, foram transferidas para meio semisólido MT para manutenção do crescimento e regeneraç̃o de plantas. Esses resultados indicam que o sistema proposto para a diluição da pressão osmótica do meio de cultivo foi eficiente, tendo permitido a multiplicaça celular sem haver rompimento das células. As colônias plaqueadas em meio sólido apresentaram ritmo acelerado de crescimento formando calos.

Os resultados deste trabalho demonstram uma metodologia eficiente para o isolamento e cultivo de protoplastos dos porta-enxertos de citros limoeiro Cravo e tangerina Cleópatra, permitindo futuros trabalhos de obtenção de híbridos somáticos através de fusáo de protoplastos.

\section{REFERENNCIAS BIBLIOGRÁFICAS}

AMARO, A. A.; ARAUJO, C. M.; PORTO, O. M.; DORNELLES, C.M. M.; CUNHA SOBRINHO, A.P.C.; PASSOS, O.S. Panorama da citricultura brasileira. In: RODRIGUEZ, O.; VIEGAS, F.; POMPEU JÚNIOR; AMARO, AA., (Eds.) Citricultura brasileira. 2.ed. Campinas, Fundaçao Cargill, 1991. p.22-54. 
CARNEIRO, V.T.C.; CONROI, T. Protoplastos de células vegetais. In: TORRES, AC.; CALDAS, L.S., (Eds.) Técnicas e aplicaç̃es da cultura de tecidos de plantas. Brasilia: EMBRAPA/CNPH, 1990. p.171-202.

CRISTOFANI, M. Adaptação de metodologias de cultura de tecidos visando o melhoramento através de indução de mutaçōes em Citrus sinensis (L) Osbeck cv. Pera. Piracicaba, 1991. 185p. Dissertação (Mestrado) - Escola Superior de Agricultura "Luiz de Queiroz", Universidade de Săo Paulo.

D'UTRA VAZ, F.B.; SANTOS, A.V.P.; MANDERS, G.; COCKNG, E.C.; DAVEY, M.R.; POWER. J.B. Plant regeneration from leaf mesophyll protoplasts of the tropical woody plant, passionfruit (Passiflora edulis fv. flancarpa Degener): the importance of the antibiotic cefotaxime in the culture medium. Plant Cell Reports, Berlim, v.12, p.220-225, 1993.

FAO QUARTELY BULLETIN OF STATISTICS. Rome, 1992, v.5. 117p.

GILMOUR, D.M.; DAVEY, M.R.; COCKING, E.C. Production of somatic hybrids tissues following chemical and electrical fusion of protoplasts from albino cell suspension of Medicago satrva and $M$. borealis. Plant Cell Reports, Berlin, v.8, p.29-32, 1989.

GLEDDIE, S.; KELLER, W.A.; SETTERFIELD, G. Produciton of new hybrid plants through protoplasts fusion. In: CHEREMISINOFF, P.N.; OVELLETTE, R.P. Biotechnolozy, applications and research. Lancaster, Technomic, 1985. p.231-242.

GOLDMAN, M.H.S. Cultura de tecidos nucelares, isolamento e radiossensitividade de protoplastos de Citrus sinensts (L) Osbeck cv. Pera. Piracicaba, 1988. 127p. Dissertaça (Mestrado) - Escola Superior de Agricultura "Luiz de Queiroz", Universidade de São Paulo.

GROSSER, J.W.; GMITTER Jr., F.G. Protoplast fusion and citus improvement. Plant Breeding Reviews, New York, v.8, p.339-374, 1990a.

GROSSER, J.W.; GMTTTER Jr., F.G. Wide-Hybridization of Citrus via protoplast fusion: progress, strategies, and limitations. Horticultural Biotechnology, Lake Alfred, 1990b. p.31-41.
HOOLEY, R.; MCCARTHY, D. Extracts from virus infected hypersensitive tobacco leaves are detrimental to protoplast survival. Physiological and Molecular Plant Pathology, London, v.16, p.25-38, 1980.

KAO, K.N. Staining methods for protoplasts and cells. In: WETTER, L.R.; CONSTABEL, F. (Eds.) Plant tissue culture methods. Ottawa, National Research Council of Canada, 1982. p.67-71.

KAO, K.N.; KELLER, W.A; MILLER, R.A. Cell division in newly formed cells from protoplasts of soybean. Experimental Cell Research, Duluth, v.62, p.338-340, 1970.

OCHATT, S.J.; COCKING, E.C.; POWER, J.B. Isolation, culture and plant regeneration of colt cherry (Prunus avium $x$ pseudocerasus) protoplasts. Plant Science, Amsterdan, v.50, p.139-143, 1987.

POWER, J.B.; DAVEY, M.R.; MCLELLAN, M.; WILSON, D. Laboratory manual; plant tissue culture. Nottingham, 1989. 57p.

SHILLITO, R.D.; PASZKOWSKI, J.; POTRYKUS, I. Agarose planting and a bed type culture technique enable and stimulate development of protoplast-derived colonies in a number of plant species. Plant Cell Reports, Berlin, v.2, p.244-247, 1983.

SPIEGELROY, P; VARDI, A Citrus. In: AMMIRATO, P.V.; EVANS, D.A; SHARP, W.R.; YAMADA, Y. (Eds.) Handbook of plant cell culture; crop species. New York: MacMillan, 1984. v.3, p.355-72.

VARDI, A;GALUN, E. Recent advances in protoplast culture of horticultural crops: citrus. Sclentia Horticulturae, Amsterdam, v.37, p.217-230, 1988.

VARDI, A; SPIEGEL-ROY, P; GALUN, E. Citrus cell culture of protoplasts, plating densities, effect of mutagens and regeneration of embryos. Plant Science Letters, Amsterdan, v.4, p.231-236, 1975.

VASIL, I.K.; VASIL, V. Isolation and culture of protoplasts. Intemational Review of Cytology, New York, Supp. v.11B, p.1-9, 1980.

ZIMMERMANN, V.; SCHEVRICH, P. High frequency fusion of plant protoplasts by eletric fields. Planta, Heidelberg, v.151, p.26-32, 1981.

Recebido para publicação em 03.08 .94

Aceito para publicação em 15.11 .94 